\title{
Evaluation of the sensory characteristics and consumer acceptability of deep-fried yam (Dioscorea rotundata) crisps in the Accra Metropolitan Area
}

\author{
Charles Tortoe ${ }^{1, ~ *}$, Papa Toah Akonor ${ }^{1}$, Stephen Nketia ${ }^{1}$, Margaret Owusu ${ }^{1}$, \\ Mary Glover-Amengor ${ }^{1}$, Lynda Hagan ${ }^{1}$, Emmanuel Otoo ${ }^{2}$ \\ ${ }^{1}$ Council for Scientific and Industrial Research, Food Research Institute, Accra, Ghana \\ ${ }^{2}$ Council for Scientific and Industrial Research, Crops Research Institute, Kumasi, Ghana \\ Email address: \\ ctortoe@yahoo.co.uk(C. Tortoe)
}

\section{To site this article:}

Charles Tortoe, Papa ToahAkonor, Stephen Nketia, Margaret Owusu, Mary Glover-Amengor, Lynda Hagan, Emmanuel Otoo. Evaluation of the Sensory Characteristics and Consumer Acceptability of Deep-Fried Yam (Dioscorea rotundata) Crisps in the Accra Metropolitan Area. Journal of Food and Nutrition Sciences. Vol. 2, No. 1, 2014, pp. 19-23. doi: 10.11648/j.jfns.20140201.13

\begin{abstract}
Deep-fried crisps snack developed from yam (Dioscorea rotundata) was evaluated for its sensory characteristics and consumer acceptability. The crisps were developed from two Ghanaian common varieties of white yam (pona and dente) using eight different seasonings. These were subjected to a sensory evaluation using 25 trained panelists to assess colour, crispiness, aroma, taste and overall acceptability. Subsequently, the two most preferred yam seasoned crisps were selected for a consumer acceptability survey using 158 respondents. In the sensory evaluation, significant difference $(p<0.05)$ was established for crispiness, taste and overall acceptability of the crisps. Ginger and shrimp seasoned crisps from pona variety was the most preferred. Regression analysis showed that taste and crispiness significantly influenced the selection of the most preferred products. In the consumer acceptability campaign, the two differently seasoned crisps were rated similarly $(p>0.05)$, although more respondents preferred the ginger seasoned crisps. Preference for the two seasoned crisps was markedly different among males and females but quite akin, considering other demographic parameters.
\end{abstract}

Keywords: Dioscorea rotundata, Deep-Frying, Crisps, Sensory Analysis, Consumer Acceptability, Accra Metropolitan Area

\section{Introduction}

Snack foods are popular and very well exploited throughout the world. They are handy and light, usually seasoned with salt and other flavorings and eaten between regular meals [1]. Snacks vary widely in their form and range from raw to cooked foods. Many snacks are processed by deep-frying and potato chips are among the most popular [2]. Deep frying is to enclose the food in a crispy crust that will retain the flavours and juices of the fried food [3]. The process involves immersing a food product in edible oil or fat, heated above the boiling point of water to achieve cooking [4]. In the process, heat and mass transfer occur concurrently between the food product and the heating medium. The water within the food is converted into steams, which effects cooking and subsequently escapes leaving spaces which are filled with the oil. This method of processing is quite rapid and convenient and imparts peculiar sensory attributes such as colour, texture and flavour and is commonly used in the snack food industry [5].

Development of snacks from yam has become attractive in the light of a search for alternative uses of root and tuber crops. Yam (Dioscorea spp.) is an important staple cultivated widely in Ghana and is ranked second most important root and tuber crop after cassava. Production of yam in Ghana has doubled over the past decade. Yam production estimates for 2009, 2010 and 2011 were 5.70, 5.96 and 5.85 million tonnes, respectively [6]. In 2011, Ghana exported approximately 27,000 MT of yam [6]. In Ghana, the white yam (Dioscorea rotundata) due to its excellent taste is mostly preferred to water yam (Dioscorea alata) and yellow yam (Dioscorea cayensis) and therefore constitutes about $80 \%$ of total yam produced in Ghana [7-10]. Typical of root and tuber crops, yam is an excellent source of energy but contains rather low amounts of fat, vitamins, proteins, and minerals $[11,12]$. Yam is also 
believed to possess medicinal properties because it contains diosgenin, a steroid saponin known to have anti-obesity effect [13].

Culinary applications of yam in Ghana has customarily been its use as a main meal when the tuber is boiled, roasted, fried, pounded or made into flour, cooked and eaten with accompaniments. The potential use of yam in producing deep-fried crisps snacks is untapped. Therefore, developing snack products from yam will further diversify its culinary uses and increase its premium as a root and tuber crop. Further, crisp from yam present the consumer with a wide array of snacks to satisfy the demands of urbanization. This is important as urbanization creates new food markets opportunities and consumers' preferred food changes from basic commodities to value-added foods [14]. According to Gehlhar and Regmi [14] the increased growth in global food markets will be realized by increased value-added food products and not through increased production volumes of basic food staples. Hence the objective of this study is laudable as it develops deep-fried yam crisps from two local varieties of Dioscorea rotundata (pona and dente), evaluate its sensory characteristics and test its consumer acceptability in the Accra Metropolitan Area.

\section{Materials and Methods}

\subsection{Materials}

Two common Ghanaian yam (Dioscorea rotundata) varieties (pona and dente) were procured from a source supplier of yams at the Haatso Yam Market in Accra and stored in a cool and dry place before processing. Matured (8 months) yams from these varieties were used to develop the deep fried crisps. Spices/seasoning (turmeric, ginger, garlic, adobo, cayenne, shrimp, ginger+garlic $(\mathrm{G}+\mathrm{G})$ and kelewele mix) and vegetable oil were obtained from a local shopping mall in Accra.

\subsection{Processing of Yam Crisps}

Matured yam tubers were carefully selected and washed by hand in potable water before peeling with sharp stainless steel blades knives. The peeled yams were secondly washed in potable water before slicing using a kitchen slicer with adjustable stainless steel blades. Frying was done in a deep fryer fitted with a temperature regulator (MCSDF15ST2, Magic Chef Inc., USA). Yam slices (2.0 mm thick) were spiced before frying for $5 \mathrm{~min}$ at $140{ }^{\circ} \mathrm{C}$. One set of yam slices from each variety, however, was not spiced before frying. Eighteen samples were obtained in all (16 seasoned and 2 unseasoned) for the sensory evaluation. In order to avoid bitterness the middle portions of $10 \mathrm{~cm}$ from head and tail of yams were used in the study. Fried slices were drained, transferred to a colander lined with tissue paper and allowed to cool. Yam crisps were then packaged in polypropylene bags and sealed with a 12" impulse bag sealer with adjustable timer (PFS-300B, Doug Care Equipment Inc., USA).

\subsection{Sensory Evaluation}

Twenty five trained panelists assessed the yam crisps. Each judge evaluated a total of eighteen yam crisps at two sessions (9 samples per session), following a randomized design matrix (XLSTAT 2012, Statsoft, France). The panelists were served with $100 \mathrm{~g}$ of each sample of yam crisps and instructed to taste and evaluate the sample using an evaluation sheet. Sensory attributes assessed included colour and colour uniformity, crispiness, aroma, taste and overall acceptability. A 7-point Hedonic scale with 1 representing 'dislike extremely' and 7 representing 'like extremely' was used for the evaluation [15-18]. Panelists were also given the option to make general comments about the samples. The evaluation was conducted in individual sensory booths consistent with ISO 8589. Unsalted cracker and water were supplied to panelists for refreshing their palates before tasting subsequent samples.

\subsection{Consumer Acceptability Survey}

Based on the outcome of the sensory evaluation, two different crisps were selected for the consumer preference test. One hundred and fifty eight consumers evaluated the yam crisps for acceptability. Participants were consumers of fried foods and were selected after reading and signing a consent form. Three pieces of each of the two yam crisps samples were presented to panelist on a white styrofoam platter, labeled with a unique 3-digit code. Unsalted cracker and water were provided to clean and refresh the palate before evaluating different samples. A 7-point Hedonic scale ranging from 1 'dislike very much' to 7 'like very much' was used to rate product acceptability as described by [15-18]. Consumers were also given the option of writing their comments about the two products. Following the acceptability test, each consumer was also made to complete a questionnaire of closed ended questions. The questionnaire was used to collect information on consumer demography and product acceptability.

\subsection{Statistical Analysis}

Individual scores from panelists were averaged and data analyzed using SPSS 17.0.1 [19]. Statistical significance was set at a level of $95 \%$ confidence interval. Stepwise regression was used to determine the influence of sensory attributes on overall acceptability of yam crisps. Chi square test was used to indicate the preference for the two yam crisps between males and females consumer surveyed.

\section{Results and Discussions}

\subsection{Sensory Evaluation}

Generally, the colour of the crisps was liked by the panelists (Table 1). The mean scores for the 18 variants of the product ranged between 3.7 and 5.9. Shrimp spiced crisps of dente variety received the lowest score rating among the yam crisps variants, followed by turmeric of pona 
variety. "No seasoning" of dente variety and kelewele of dente variety had a mean score of 4.5 . The $\mathrm{G}+\mathrm{G}$ of dente variety and garlic of pona variety were the most highly rated in terms of their colour and were rated as "like moderately" of 5.9 and 5.5, respectively. Colour is one of the most important physical attribute that greatly influences consumer perception and can summarily lead to rejection of a product. Consumers tend to associate colour with sensory and physicochemical attributes of products because they correlate [20]. Additionally, Miranda and Aguilera [21] observed that during frying, the colour of the product is developed as a result of Maillard and is influenced by factors such as reducing sugar and amino acid content.

Development of a crispy, crunchy and crackly texture is one of the distinct properties of fried food products and considerably affects acceptability. Generally, crispiness was rated high by participants, with the highest rated sample obtaining a mean score of 5.9. This score can be described as 'like moderately' on the 7-point Hedonic scale. Conversely, cayenne of pona variety had the lowest score of 3.5 and panelists were indifferent (neither like nor dislike) about its crispiness. These two samples were judged as markedly different $(p<0.05)$ from one another. Differences in crispness could arise from air spaces that may develop within the crisp structure [22], sogginess, moisture uptake after frying [21] as well as differences in starch and other chemical components of the food product [23].

Aroma of the crisps was not significantly different $(p>0.05)$ from each other and was generally rated as 'like slightly' by the 25-man panel. This outcome was regardless of the fact that different seasonings were used for each of the variants, apart from the control. Regarding the taste, only shrimp dente variety was perceived significantly different $(p<0.05)$ from the rest of the samples. Incidentally, this particular sample also had the least score for taste (3.6).

The lowest mean score of 3.3 was obtained for overall acceptability by shrimp dente variety. It was considerably different from ginger pona variety and shrimp pona variety for overall acceptability. The shrimp seasoned dente variety also had low scores for colour and taste, an indication that this sample was generally undesirable by the panel. All other crisps variants were acceptable to the panel since they scored more than 3.5 (neither like nor dislike) on the 7-point Hedonic scale. Based on the mean overall acceptability ginger-flavoured pona variety crisps and shrimp-flavoured pona crisps were selected for the consumer acceptability survey. This reiterates the point that pona has always been the mostly preferred white yam variety in Ghana [7-9]. There was a strong correlation $\left(\mathrm{R}^{2}=0.619\right)$ between the overall acceptability and the sensory attributes of the yam crisps. A stepwise multiple regression between overall preference and sensory attributes showed that taste and crispiness significantly $(p<0.05)$ affected acceptability and were therefore the best predictors of crisps acceptability. Taste and crispiness accounted for $62 \%$ of the variability in the relationship between the sensory attributes and overall preference. This finding underscores the focal role of taste as an essential attribute of food products and affirms the observation by Kita [23] and Krokida, Oreopoulou, Maroulis, Marinos-Kouris [24] that crispness is an important texture property of fried chips.

Table 1. Mean of Hedonic ratings for sensory attributes and overall acceptability of yam crisps.

\begin{tabular}{|c|c|c|c|c|c|c|}
\hline \multirow[b]{2}{*}{$\begin{array}{l}\text { Sample } \\
\text { code }\end{array}$} & \multirow[b]{2}{*}{$\begin{array}{c}\text { Seasonin } \\
\mathrm{g}\end{array}$} & \multicolumn{5}{|c|}{ Mean score for attributes } \\
\hline & & $\begin{array}{c}\text { Colou } \\
\mathrm{r}\end{array}$ & $\begin{array}{l}\text { Crispine } \\
\text { ss }\end{array}$ & $\begin{array}{c}\text { Arom } \\
\mathrm{a}\end{array}$ & $\begin{array}{c}\text { Tast } \\
\mathrm{e}\end{array}$ & $\begin{array}{l}\text { Acceptabili } \\
\text { ty }\end{array}$ \\
\hline Dente & Ginger & 4.7 & $4.8^{\mathrm{ab}}$ & 5.2 & $4.7^{\mathrm{ab}}$ & $4.1^{\mathrm{ab}}$ \\
\hline Dente & $\begin{array}{c}\text { Cayenn } \\
\mathrm{e}\end{array}$ & 5.3 & $5.3^{\mathrm{ab}}$ & 5.5 & $4.7^{\mathrm{ab}}$ & $4.7^{\mathrm{ab}}$ \\
\hline Dente & $\mathrm{G}+\mathrm{G}$ & 5.9 & $4.6^{\mathrm{ab}}$ & 4.4 & $4.0^{\mathrm{ab}}$ & $4.0^{\mathrm{ab}}$ \\
\hline Dente & Shrimp & 3.7 & $4.2^{\mathrm{ab}}$ & 4.2 & $3.6^{\mathrm{a}}$ & $3.3^{\mathrm{a}}$ \\
\hline Dente & $\begin{array}{c}\text { Turmeri } \\
\mathrm{c}\end{array}$ & 4.3 & $5.9^{\mathrm{b}}$ & 4.9 & $4.5^{\mathrm{ab}}$ & $4.5^{\mathrm{ab}}$ \\
\hline Dente & $\begin{array}{c}\text { Adobo } \\
\circledR\end{array}$ & 5.0 & $5.1^{\mathrm{ab}}$ & 5.1 & $4.5^{\mathrm{ab}}$ & $4.3^{\mathrm{ab}}$ \\
\hline Dente & $\begin{array}{c}\text { "No } \\
\text { seasonin } \\
\text { g" }\end{array}$ & 4.5 & $5.3^{\mathrm{ab}}$ & 4.6 & $4.0^{\mathrm{ab}}$ & $4.2^{\mathrm{ab}}$ \\
\hline Dente & $\begin{array}{c}\text { Kelewel } \\
\mathrm{e}\end{array}$ & 4.5 & $5.1^{\mathrm{ab}}$ & 4.8 & $4.1^{\mathrm{ab}}$ & $4.2^{\mathrm{ab}}$ \\
\hline Dente & Garlic & 4.9 & $4.9^{\mathrm{ab}}$ & 4.3 & $4.2^{\mathrm{ab}}$ & $3.8^{\mathrm{ab}}$ \\
\hline Pona & Ginger & 5.1 & $4.6^{\mathrm{ab}}$ & 5.2 & $4.8^{\mathrm{ab}}$ & $5.1^{\mathrm{b}}$ \\
\hline Pona & $\begin{array}{c}\text { Cayenn } \\
\mathrm{e}\end{array}$ & 4.6 & $3.5^{\mathrm{a}}$ & 4.2 & $4.4^{\mathrm{ab}}$ & $3.9^{\mathrm{ab}}$ \\
\hline Pona & $\mathrm{G}+\mathrm{G}$ & 5.4 & $4.5^{\mathrm{ab}}$ & 4.4 & $4.5^{\mathrm{ab}}$ & $4.1^{\mathrm{ab}}$ \\
\hline Pona & Shrimp & 5.1 & $4.2^{\mathrm{ab}}$ & 5.0 & $5.7^{\mathrm{b}}$ & $5.2^{\mathrm{b}}$ \\
\hline Pona & $\begin{array}{c}\text { Turmeri } \\
\text { c }\end{array}$ & 4.5 & $5.2^{\mathrm{ab}}$ & 4.8 & $4.3^{\mathrm{ab}}$ & $4.9^{\mathrm{ab}}$ \\
\hline Pona & $\begin{array}{c}\text { Adobo } \\
\mathbb{R}\end{array}$ & 5.2 & $4.2^{\mathrm{ab}}$ & 4.5 & $4.9^{\mathrm{ab}}$ & $4.5^{\mathrm{ab}}$ \\
\hline Pona & $\begin{array}{c}\text { "No } \\
\text { seasonin } \\
\text { g" }\end{array}$ & 4.9 & $4.6^{\mathrm{ab}}$ & 4.7 & $4.4^{\mathrm{ab}}$ & $4.1^{\mathrm{ab}}$ \\
\hline Pona & $\begin{array}{c}\text { Kelewel } \\
\mathrm{e}\end{array}$ & 5.1 & $4.5^{\mathrm{ab}}$ & 4.0 & $3.9^{\mathrm{ab}}$ & $3.9^{\mathrm{ab}}$ \\
\hline Pona & Garlic & 5.5 & $4.2^{\mathrm{ab}^{*}}$ & 4.3 & $4.4^{\mathrm{ab}}$ & $4.5^{\mathrm{ab}}$ \\
\hline
\end{tabular}

Means with different superscripts are significantly different at $\mathrm{p}<0.05$. Italicized samples were selected for the consumer acceptability survey.

Table 2. Regression between acceptability and sensory attributes.

\begin{tabular}{cccc}
\hline Parameter & $\begin{array}{c}\text { Acceptability } \\
\text { estimates }\end{array}$ & $\begin{array}{c}\text { SE of } \\
\text { estimates }\end{array}$ & p-value \\
\hline Intercept & -0.040 & 1.015 & 0.969 \\
Crispiness & 0.291 & 0.120 & $0.034^{*}$ \\
Taste & 0.667 & 0.207 & $0.008^{*}$ \\
\hline
\end{tabular}

*Significant at $\mathrm{p}<0.05 .{ }^{\dagger}$ Colour and aroma were excluded from the model because they were not influential predictors of crisps acceptability

\subsection{Consumer Demography}

Panelist who participated in the consumer survey was 57\% male and $43 \%$ female. Majority $(66.4 \%)$ were aged between 18 and 35 years (Table 3). The participants were largely literate, $35.5 \%$ were tertiary level graduates and the remaining $64.5 \%$ were secondary or basic school level graduates. Additionally, $81 \%$ of participants came from households with four or more members [25] while the remaining had households' less than four members. 
Table 3. Demographic characteristics of participants.

\begin{tabular}{cccccc}
\hline Variable & Frequency & $\begin{array}{c}\text { Percentage } \\
(\%)\end{array}$ & $\begin{array}{c}\text { Preferred } \\
\text { sample }\end{array}$ & $\chi^{2}$ & p-value \\
\hline Gender & & & & & \\
Male & 90 & 57.0 & 788 & 5.104 & 0.024 \\
Female & 68 & 43.0 & 416 & & \\
Age $(n=152)$ & & & & & \\
$18-35$ & 101 & 66.4 & 416 & & \\
$36-45$ & 18 & 11.8 & 416 & 5.017 & 0.286 \\
$46-55$ & 20 & 13.2 & 788 & & \\
$>55$ & 13 & 8.5 & 788 & & \\
Educational level $(n=155)$ & & & & \\
Primary & 17 & 11.0 & 788 & 5.468 & 0.065 \\
Secondary & 83 & 53.5 & 416 & & \\
Tertiary & 55 & 35.5 & 788 & & \\
Household size & & & & & \\
2 or less & 10 & 6.3 & 788 & 2.797 & 0.731 \\
3 & 20 & 12.7 & 416 & & \\
4 & 26 & 16.5 & 788 & & \\
$>4$ & 102 & 64.6 & 416 & & \\
\hline
\end{tabular}

\subsection{Consumer Acceptability}

Ginger seasoned crisp was the most preferred among the selected crisps variants and was the choice of $52.2 \%$ of 158 consumers surveyed. However, the mean acceptability score assigned was not significantly different $(p>0.05)$ among the two samples, although the ginger flavoured crisps had a higher mean rating of 6.5 (Table 4 ). This observation verifies the results of the sensory evaluation conducted prior to the consumer acceptability survey, which also had acceptability scores not being significantly different $(p>0.05)$ between these two samples.

Chi square test indicated that acceptability of the two yam crisps was significantly different $(p<0.05)$ between males and females with a majority of females liking shrimp seasoned crisps most and males preferring ginger seasoned crisps most(Table 3). Apart from gender, no clear trend in acceptability was established for the fried yam crisps with respect to the other demographic indices. Consumers with different social status rated the crisps similarly, an observation which indicates that the developed yam crisps would be widely acceptable, regardless of demographic status.

Table 4. Mean score for yam crisps acceptability.

\begin{tabular}{|c|c|c|c|c|}
\hline $\begin{array}{l}\text { Seasoning/ } \\
\text { flavour }\end{array}$ & Percentage & $\begin{array}{c}\text { Mean } \\
\text { score }\end{array}$ & Inference & $p$-value \\
\hline Ginger & 52.2 & $6.5 \pm 0.6$ & $\begin{array}{l}\text { Like very } \\
\text { much }\end{array}$ & $<0.514$ \\
\hline Shrimp & 47.8 & $6.4 \pm 0.6$ & $\begin{array}{c}\text { Like } \\
\text { moderately }\end{array}$ & \\
\hline
\end{tabular}

Reasons for consumers' choice of the fried yam crisps were based on taste, texture and a combination of taste and texture as indicated in figure 1. This trend was similar among the two variants of yam crisps. A remarkable observation of this result is the fact that none of the participants' choice was influenced by colour or aroma.

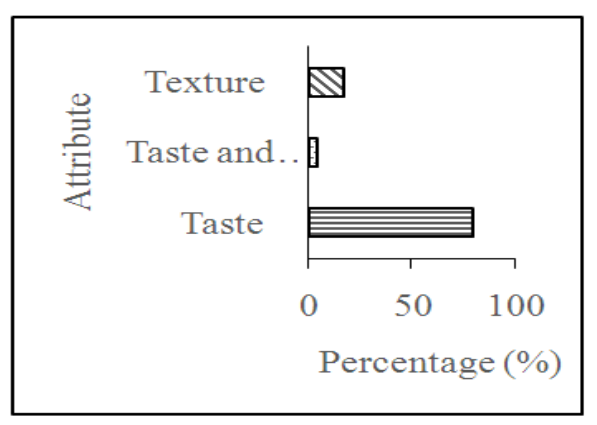

Figure 1.Attributes of fried yam crisps that influence acceptability.

This lends credence to the findings from the regression analysis conducted on the responses from the sensory assessment (Table 2). Even though these attributes may greatly influence the acceptability of certain food products, they may be described as secondary attributes for consumer acceptability of deep-fried yam crisps.

\section{Conclusion}

Sensory evaluation of the deep-fried yam crisp showed acceptability for samples from pona variety as opposed to samples from dente variety with taste and texture (crispiness) influencing selection of preferred choice. Two other attributes, colour and aroma did not contribute significantly to the preferred option of sensory panelists. Yam crisps seasoned with ginger or shrimp were liked most compared to crisps seasoned with the other six spices. Consumer acceptability survey revealed that more consumers $(>52 \%)$ liked the ginger-seasoned crisps than shrimp seasoned crisps $(<48 \%)$. Although, gender influenced the choice of deep fried yam crisps, other demographic indices such as age, educational status and household size of consumer did not. Generally, the developed yam crisps was acceptable since it had an acceptability score of $6.4-6.5$ as 'like moderately' to 'like very much' on a 7-point Hedonic scale.

\section{Acknowledgements}

The authors are grateful for the financial support from the Ministry of Agriculture and Fisheries of Japan and Mitsubishi Research Institute, Inc. Japan.

\section{References}

[1] Lusas EW (2001). Overview. In: Lusas EW, Rooney LW (eds.), Snack Foods Processing, CRC Press LLC, Boca Raton.

[2] Salvador A, Varela P, Sanz T, Fiszman SM (2009). Understanding potato chips crispy texture by simultaneous fracture and acoustic measurements and sensory analysis. LWT. 42, 763-767.

[3] Mallikarjunan PK, Ngadi MO, Chinnan MS (2010). Breaded fried foods. CRC Press, Boca Raton. 
[4] Mariscal M, Bouchon P (2008). Comparison between atmospheric and vacuum frying of apple slices. Food Chem.107, 1561-1569.

[5] Chen Y, Moreira RG (1997). Modeling of a batch deep-fat frying process for tortilla chips. Trans IChem.75, 181-190.

[6] MoFA (2013). Agriculture in Ghana, Facts and Figures, Statistics Research and Information Directorate (SRID), Ministry of Food and Agriculture, Ghana.

[7] Aidoo R (2009). An analysis of yam consumption patterns in Ghanaian urban communities. A PhD thesis submitted to the Kwame Nkrumah University of Science and Technology. Kumasi, Ghana.

[8] IITA (2001). "Yam", An IITA Publication. International Institute of Tropical Agriculture (IITA). Ibadan, Nigeria.

[9] Bancroft RD (2000). Relieving post-harvest constraints and identifying opportunities for improving the marketing of fresh yam in Ghana, $1^{\text {st }}$ January- $31^{\text {st }}$ March, 2000. Final Project Report No: R6505. Natural Resources Institute, University of Greenwich, Chatham, Kent, UK. 51 pp.

[10] Tetteh JP, Saakwa C (1994). Prospects and constraints of yam production in Ghana. In Ofori A, Halm, C (ed). Proceedings of $9^{\text {th }}$ Symposium of the International Society for Tropical Root Crops, Accra, Ghana. pp. 20-26.

[11] Afoakwa EO, Sefa-Dedeh S (2001). Chemical composition and quality changes occurring in Dioscorea dumetorum pax tubers after harvest. Food Chem.75, 85-91.

[12] Shanthakumari S, Mohan VR, de Britto J (2008). Nutritional evaluation and elimination of toxic principles in wild yam (Dioscorea spp.). Trop SubtropAgrosys.8, 319-325.

[13] Kwon CS, Sohn HY, Kim SH, Kim JH, Son KH, Lee JS, Lim JK, Kim JS (2003). Anti-obesity effect of Dioscorea nipponica Makino with lipase-inhibitory activity in rodents. Biosci Biotech Biochem. 67, 1451-1456.

[14] Gehlhar M, Regmi A (2002). Shaping the global market for high value foods. World Agriculture and Trade, Agricultural
Outlook/ December 2002, Economic Research Service/USDA, Washington.

[15] Stone H. Sidel JL (2004). Sensory Evaluation Practices, $3^{\text {rd }}$ Edition. Elsevier Academic Press, San Diego, California, pp. $247-277$.

[16] Lawless HT, Heymann H (2010). Sensory evaluation of food principles and practices, 2nd edition, Springer Science and Business Media, LLC, New York.

[17] Rampersad R, Badrie N, Comissiong E (2003). Physiochemical and sensory characteristics of flavored snacks from extruded cassava/pigeon pea flour. J Food Sci.68, 363-367.

[18] Hooda S, Jood S (2005). Organoleptic and nutritional evaluation of wheat biscuits supplemented with untreated and treated fenugreek flour. Food Chem.3, 427-435.

[19] SPSS (2008). SPSS Statistics v. 17.0.1. SPSS Inc., Chicago III.

[20] Pedreschi F, Mery A, Domingo M, Marique T (2007). Quality evaluation and control of potato chips and French fries. In: Sun DW (eds.), Computer vision technology for food quality evaluation, Academic Press, pp. 549-570.

[21] Miranda MML, Aguilera JM (2006). Structure and texture properties of fried potato products. Food Rev Int.22,173-201.

[22] Vincent JFV (1998). The quantification of crispness. J Sci Food Agric.78, 162-168.

[23] Kita A (2002). The influence of potato chemical composition on crisp texture. Food Chem.76, 173-179.

[24] Krokida MK, Oreopoulou V, Maroulis ZB, Marinos-Kouris D (2001). Effect of pre-treatment on viscoelastic behavior of potato strips. J Food Eng.50, 11-17.

[25] GSS (2012). The 2010 population and housing census. Summary report of final results. Ghana Statistical Service. Accra, Ghana. 